\title{
Gossypiboma as an unusual cause of altered bowel habit
}

\author{
Sarvnaz Sepehripour, ${ }^{1}$ George Filobbos, ${ }^{2}$ Nigel Suggett ${ }^{3}$ \\ ${ }^{1}$ Department of General Surgery, Frenchay Hospital, Bristol, UK \\ ${ }^{2}$ Department of Surgery, University Hospital Birmingham, Birmingham, UK \\ ${ }^{3}$ Department of Colorectal Surgery, University Hospital Birmingham, Birmingham, UK \\ Correspondence to George Filobbos, gfilobbos@yahoo.com
}

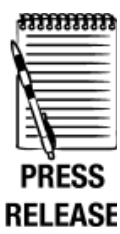

\section{DESCRIPTION}

Gossypiboma is the term for a surgical swab accidentally left inside a patient's body. It is derived from the Latin word 'gossypium' meaning cotton and the Swahili 'boma' meaning place of concealment. ${ }^{1}$ Gossypiboma has an incidence of 1:1500 for intra-abdominal operations. ${ }^{2}$ Common presentations of gossypiboma are abdominal distension, ileus, tenesmus, pain, palpable mass, vomiting, weight loss, diarrhoea, abscess and fistula formation. ${ }^{3}$ In addition to the physical and psychological impact on the patient, retained surgical equipment cost the National Health Services the equivalent of $\$ 12.8$ million over the past 5 years (figures 1 and 2 ).

A 56-year-old woman presented with alteration of bowel habit 6 months after sacrohysteropexy. The swab was seen on CT in the pelvic cavity surrounded by a collection $15 \mathrm{~cm}$ above the anus and boring its way into the rectum. The swab was successfully removed by rigid sigmoidoscopy using a laparoscopic grasping forceps thus avoiding a laparotomy and avoiding a defunctioning colostomy. The patient had the procedure under general anaesthetic and was consented for laparotomy. The patient had an uneventful postoperative period with improvement of her symptoms. We have followed her up for 5 months and there was no development of pelvic sepsis.

To the best of our knowledge there are no other cases in the literature where a missed swab was removed by sigmoidoscopy.

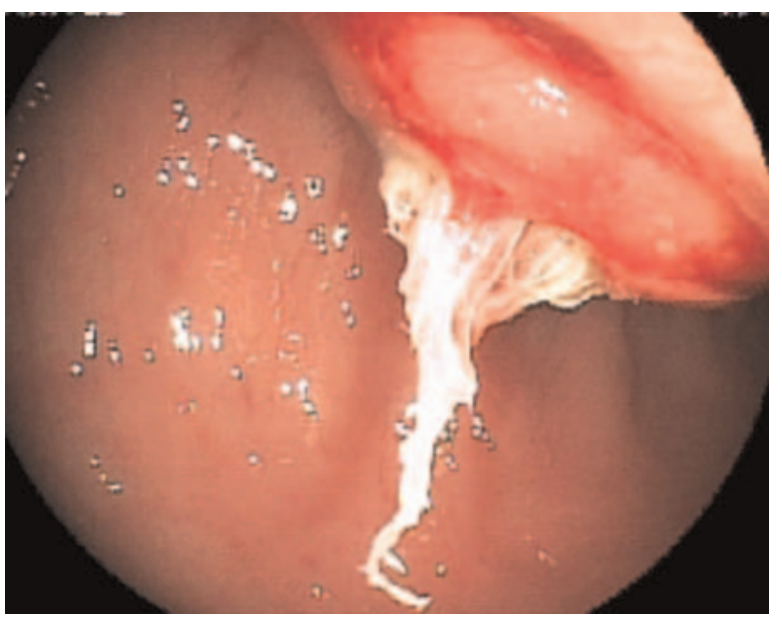

Figure 1 The swab protruding into the rectum.
Unfortunately, most reported cases of gossypiboma, despite being a 'never event', occur in the presence of a normal pack count which underlines the necessity of vigilance of all theatre staff to prevent this avoidable complication

\section{Learning points}

- In order to avoid gossypiboma, one cannot put enough emphasis on thorough swab counting. The golden dictum stating that prevention is better than cure invariably applies to all cases of gossypiboma.

- Despite thorough swab counts, the diagnosis of gossypiboma should be borne in mind in patients with a history of previous surgery.

- In selected cases where the swab has started to penetrate the wall of the intestine, an attempt of removal through sigmoidoscopy might spare the patient a laparotomy.

Contributors All authors have equally contributed to this submission. Competing interests None.

Patient consent Obtained.

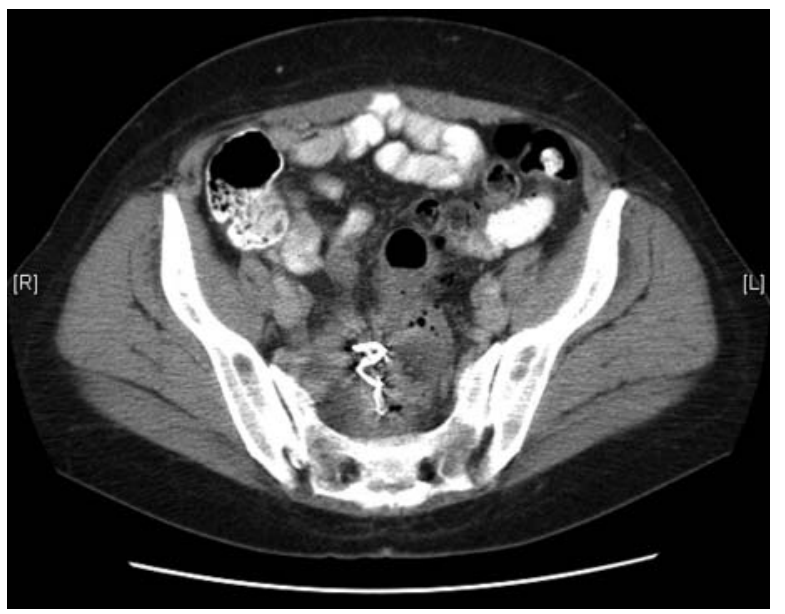

Figure 2 CT image showing the retained foreign body. 


\section{BMJ Case Reports}

\section{REFERENCES}

1. Zbar AP, Agrawal A, Saeed IT, et al. Gossypiboma revisited: a case report and review of the literature. J R Coll Surg Edinb 1998;43:417-18.

2. Gencosmanoglu $\mathbf{R}$, Inceoglu $R$. An unusual cause of small bowel obstruction: gossypiboma-case report. BMC Surg 2003;3:6.
3. Mahalik SK, Puneet Gupta SK, et al. Gossypiboma: intramural and transmural migration causing small bowel obstruction. ANZ J Surg 2008;78:417-18.

This pdf has been created automatically from the final edited text and images.

Copyright 2012 BMJ Publishing Group. All rights reserved. For permission to reuse any of this content visit http://group.bmj.com/group/rights-licensing/permissions.

BMJ Case Report Fellows may re-use this article for personal use and teaching without any further permission.

Please cite this article as follows (you will need to access the article online to obtain the date of publication).

Sepehripour S, Filobbos G, Suggett N. Gossypiboma as an unusual cause of altered bowel habit. BMJ Case Reports 2012;10.1136/bcr-2012-006316, Published XXX

Become a Fellow of BMJ Case Reports today and you can:

- Submit as many cases as you like

- Enjoy fast sympathetic peer review and rapid publication of accepted articles

- Access all the published articles

- Re-use any of the published material for personal use and teaching without further permission

For information on Institutional Fellowships contact consortiasales@bmjgroup.com

Visit casereports.bmj.com for more articles like this and to become a Fellow 